\title{
Trade Sanctions, Financial Transfers and BRIC's Participation in Global Climate Change Negotiations
}

\author{
HUIFANG TIAN \\ JOHN WHALLEY
}

CESIFo Working PAPER NO. 2698

Category 8: Trade Policy

JULY 2009
An electronic version of the paper may be downloaded
- from the SSRN website: Www.SSRN.com
- from the RePEc website: Www.RePEc.org
- from the CESifo website: www.CESifo-group.org/wp




\title{
Trade Sanctions, Financial Transfers and BRIC's Participation in Global Climate Change Negotiations
}

\begin{abstract}
Countries can reduce global emissions by reducing own consumption since they are linked to the total value of consumption world wide. Two effects are at issue: a utility loss from forgone consumption and a utility gain from lowered temperature change. It is thus unclear whether own country emissions reductions are in the self interest; typically they are not for small countries, but may be for larger countries. Here are investigate the incentives for individual large population low wage rapidly growing countries in the BRIC group (Brazil, Russia, India, China) and the groups of countries as a sub-global coalition. We also assess what level of other countries' trade measures linked to non participation is needed to induce compliance as an all or nothing discrete choice. We capture induced changes in the global trade equilibrium in our analysis, as well as participation linked to financial transfers. Our results suggest that only very high tariffs over a hundred percent by all other countries, or even higher tariffs by the OECD alone, could induce participation by BRIC countries, especially when the country is a net exporter. Equally, large financial transfers would be needed.
\end{abstract}

JEL Code: A11.

Keywords: trade sanctions, financial transfers, global emissions, climate change.

Huifang Tian

Chinese Academy of Social Science (CASS) tianhf@cass.org.cn
John Whalley

University of Western Ontario

jwhalley@uwo.ca

May 2009

We are grateful for financial support to the Centre for International Governance Innovation(CIGI), Waterloo, Ontario, the Academic Development Fund of the University of Western Ontario, and to the Ontario Research Fund (ORF-R3). 


\section{Introduction}

In this paper we explore what might induce the participation of Brazil, Russia, India and China (the BRICs) in global climate change negotiations. In the current global negotiation situation in which arrangements for a post-Kyoto regime are to be worked out in Copenhagen in 2009 in a further UNFCCC negotiation, the participation of the largest non OECD global emitters is seen as especially key. But it has been noted extensively in the literature on international environmental agreements (see Barrett (1994)) that country own incentives to participate in negotiations on them are small since the benefits of country actions to internalize externalities accrue to all countries while the costs are borne solely by the country itself. Shapley and Shubik (1967) characterize this as the possibility that the core in an externality game maybe empty.

Cai, Riezman and Whalley (2008) have recently developed a numerical simulation capability using a formulation related to that in Uzawa (2004) to explore in a calibrated global warming model at what levels of global damage and speeds of temperature change participation would be in the self interest of large countries or regions. Here we use an extended version of this framework to explore what level of trade measures against them and by whom can induce participation, using trade measures as a penalty to non-participation. We also explore the related issue of the size of financial transfers that would also induce participation.

We first present our analytical model. We consider multiple regions (US, EU, China, India, Brazil, Russia, others), each of whom have preferences defined over goods and (negatively in ways we set out below) over damage from temperature change. Each country is endowed with a single good and goods are heterogeneous across countries (the Armington (1969) assumption). This latter feature captures trade 
and allows us to analyze the impact of trade sanctions which reduce foreign purchases of their own good.

In the model, countries can reduce global emissions by forgoing consumption since they are linked to the total value of consumption world wide. In this way, they induce lowered world temperature change for all, but at a cost to themselves. The model thus allows us to evaluate whether own country emissions reductions are in the self interest of individual countries (or groups of countries as sub-global coalitions). This structure also captures the impacts of country actions on trade or financial transfers between countries with induced changes in the global trade equilibrium. We can thus also evaluate the impact of trade sanctions by individual countries or groups of countries or financial transfers linked to participation by BRIC countries as an all or nothing discrete choice.

We use data on emissions and GDP by countries for 2006, and also data on average annual country growth rates over the period 2004-2006 to construct business-as-usual (BAU) scenarios for the 50 year period 2006-2056. In our model analysis we alternatively treat each of these groups of years as a single period for the purposes of model analysis. Effectively, we use single period analysis, but the period is 30,50 or 80 years.

We also include in this structure a function relating temperature change to emissions growth which we calibrate to conjectures advanced in the Stern (2006) report of $3^{\circ} \mathrm{C}$ temperature change within 30 years and 5 temperature change in 50 years under BAU. We use alternative estimates of global damage (assumed equi-proportional for all countries) from these temperature changes suggested in Stern (or up to $20 \%$ world product by 2050) and by Mendelsohon (2007) (of less than $1 \%$ of world product by 2050) to calibrate preferences toward temperature change. In our 
formulation these embody the damage costs of climate change in welfare form.

Our results suggest that given the Armington treatment and an extreme endowment assumption (countries are endowed only with their own goods) there are always trade sanctions on net importers that induce participation. But only very high tariffs of several hundred percent by all other countries, or even higher tariffs by the OECD alone can induce participation by the rapid growing non OECD BRIC countries. Equally, large financial transfers would be needed to encourage developing countries' join in the agreement.

And these also vary with assumed substitution elasticities in preferences and critically depend on the assumed damage associated with climate change and on whether PPP measure, discount growth or emission reduction cost has been taken into consideration. A country's likelihood of participation also increases the larger the number of other countries who make financial transfer to them. 


\section{Theoretical Analysis- $\mathbf{N}$ country $\mathbf{N}$ good case with temperature change}

Global warming negotiations aim at achieving joint carbon emission abatement in the presence of externality effects across countries. The first round of global negotiations in this vein concluded in Kyoto 1997, and now continue in the current post Bali road map negotiations set to conclude in Copenhagen in 2009 with agreement for the period after 2012. These negotiations aim to achieve joint mutual agreement to act, and will only conclude when all parties accept each others commitments. More detailed discussion of these negotiations is given in Walsh and Whalley (2008) and Tian and Whalley (2008).

In this paper, we focus on the incentives to participate in negotiation, rather than the outcome of such negotiations; effectively what level of trade policy (explicit trade sanctions) and financial transfers can induce participation. We begin with the $\mathrm{N}$ good, $\mathrm{N}$ country case. Empirically based analyses follow.

The literature by Debreu and Scarf (1967) and Shapley and Shubik (1969) suggests that collective global agreement on carbon emission reduction where side payments do not occur may not be feasible since the number of countries participating in the agreement would need to be small to achieve mutual agreement since each country can free-ride without any punishment. The likelihood of positive participation also depends critically on the severity of damage from the externality.

Cai, Riezman and Whalley (2008) explore in a calibrated global warming model that international trade can be a positive factor in motivating international negotiation on climate change. We further develop Cai, Riezman and Whalley's model and take tariffs and financial transfers into consideration. We use data on consumption and trade for these economies and along with country growth profiles analyze changes in various damage and temperature change assumptions for business as usual scenarios 
and undertake numerical investigation with our analytical structure. The base data is for a single 50 year period 2006-2056 with assumed yearly growth rates over the period. We use calibration to a temperature change function for prospective changes in temperature under a business as usual scenario out to 2056, and use varying estimates of associated damage over the ranges reported by Stern (2007) and Mendelsohn (2007).

\subsection{Temperature change and top level utility function}

We analyze a single period of a number of years during which each economy grows. We assume that consumption of the good by the country directly generates emissions of carbon which in turn raise global temperature. Countries receive positive utility from consumption but negative utility from temperature change. Countries thus have an upper bound on own consumption reflecting a BAU scenario, and if they consumes less than the upper bound they experience less temperature change. If they are small, their own actions have little or no effect on temperature change.

As we will later work with the impacts of agreements to reduce carbon emissions over a given period of time, the single period model covers 50 years. In this 50 year period, we focus on changes in consumption (use of own and foreign goods) and utility, and measure changes in these variables relative to the outcome of zero growth over the period. The utility function is thus defined over 50 year changes in consumption and temperature change. Potential use of the good reflects changes in potential output from the economy over 50 years. We first analyze a business as usual (BAU) scenario which reflects current observed growth rates remaining unchanged over 50 years, and with no global or single country emissions limitation initiatives in place. 
The utility of each country is reflected in a utility change function with arguments given by its own change in composite consumption as well as the temperature change of the world. Without loss of generality, we initially assume the utility change function for each country has a Cobb-Douglas form given by (1) and later use CES and alternative forms.

$$
\Delta U^{i}=\Delta U\left(\Delta R C_{i}, \Delta T\right)=\Delta R C_{i} *\left(\frac{C-\Delta T}{C}\right)^{\beta}
$$

In this specification, $\Delta R C_{i}$ represents change in the composite consumption good for each country i. C can be thought of the global temperature change at which all economic activity ceases (say $20^{\circ} \mathrm{C}$ ). In this case, as $\Delta T$ approaches $\mathrm{C}$, utility goes to zero, and, as $\Delta T$ goes to zero there is no welfare impact of temperature change. Utility change over the model period (2006-2056) increases as temperature change falls. The share parameter $\beta$ reflects the severity of damage (in utility terms) from temperature change, which we later calibrate to various damage estimates from business as usual global temperature change reported by Stern (2006) and Mendelsohn (2007).

Global temperature change, in turn, is determined by the change in carbon emissions over the period across all countries in the model. We adopt a simple temperature change function and assume that emissions by each country equal the change in consumption times country emissions intensity (emissions/GDP) so as to allow for differing emissions intensities by country. Defining the emissions intensity of country $i$ as $e_{i}$, we use a simple power function (2) for global temperature change due to changes in emissions by all countries over the model period.

$$
\Delta T=g\left(\sum_{i} e_{i} \Delta R S_{i}\right)=a\left(\sum_{i} e_{i} \Delta R S_{i}\right)^{b}+c
$$


In this case, $\Delta R S_{i}$ represents the change in the sales (production) of the own good for each country $i$. Consumption in each country is given by $\Delta R C_{i} \leq \Delta R S_{i}$ because of international trade.

In this structure, a carbon reduction commitment by a single country implies a reduction in composite consumption, and this has both negative and positive effects on utility change for the countries over the model period. On the one hand, a reduction in consumption lowers utility for the country, but on the other hand, country consumption reductions lower global emissions and hence world temperature change, and increases the utility both of the country reducing the emissions and all other countries.

\subsection{Composite consumption goods by country}

The composite consumption good $R C_{i}$ is a CES function of domestic and imported consumption goods, which is similar that used in the nested CES Armington models (see Whalley (1985)). The model effectively becomes an Armington N good $\mathrm{N}$ country pure trade economy in which the endowment is variable.

$$
\begin{gathered}
\operatorname{Max} R C_{i}=R C\left(D_{i}, M_{i}\right)=\left(\left(\lambda_{1}^{i}\right)^{\frac{1}{\sigma}} D_{i}^{\frac{\sigma-1}{\sigma}}+\left(\lambda_{2}^{i}\right)^{\frac{1}{\sigma}} M_{i}^{\frac{\sigma-1}{\sigma}}\right)^{\frac{\sigma}{\sigma-1}} \\
\text { s.t. } p_{i}^{w} D_{i}+P_{i}^{m} M_{i} \leq I_{i}=p_{i}^{w} R S_{i}
\end{gathered}
$$

where $D_{i}$ and $M_{i}$ represent consumption of the domestic and a composite imported good respectively with $p_{i}^{w}$ and $P_{i}^{m}$ as their prices, $\lambda_{1}^{i}$ and $\lambda_{2}^{i}$ as the consumption shares, and $\sigma$ as the substitution elasticity. The composition of $M_{i}$ is determined by the third level of the model, and $P_{i}^{m}$ is a price index of seller's prices $p_{j}^{w}$ (see equation (8)). 
Demands for domestic consumption goods and imported consumption goods are:

$$
\begin{aligned}
& M_{i}=\frac{\lambda_{2}^{i} I}{\left(P_{i}^{m}\right)^{\sigma}\left(\lambda_{1}^{i}\left(p_{i}^{w}\right)^{(1-\sigma)}+\lambda_{2}^{i}\left(P_{i}^{m}\right)^{(1-\sigma)}\right)} \\
& D_{i}=\frac{\lambda_{1}^{i} I}{\left(p_{i}^{w}\right)^{\sigma}\left(\lambda_{1}^{i}\left(p_{i}^{w}\right)^{(1-\sigma)}+\lambda_{2}^{i}\left(P_{i}^{m}\right)^{(1-\sigma)}\right)}
\end{aligned}
$$

\subsection{Composite of Imported Goods}

The CES composite commodities at the third level of nesting are composites of imported goods for each country. Given that each country has one good it can sell, but N-1 goods it consumes, the CES composite of other goods defines an import composite. This is the outcome of a sub-utility maximization exercise

$$
\begin{gathered}
\operatorname{Max} M_{i}=H\left(R_{1}^{i}, R_{2}^{i}, \ldots, R_{i-1}^{i}, R_{i+1}^{i}, \ldots, R_{N}^{i}\right)=\left(\sum_{j \neq i}\left(\kappa_{j}^{i}\right)^{\frac{1}{\sigma_{m}}}\left(R_{j}^{i}\right)^{\frac{\sigma_{m}-1}{\sigma_{m}}}\right)^{\frac{\sigma_{m}}{\sigma_{m}-1}} \\
\text { s.t. } \sum_{j \neq i} p_{j}^{d} R_{j}^{i} \leq I_{i}^{m}=P_{i}^{m} M_{i}
\end{gathered}
$$

where $R_{j}^{i}$ is the imported $\operatorname{good} i$ by country $j$ and $P_{i}^{m}$ is the composite import price for country $i, \kappa_{j}^{i}$ is the consumption share and $\sigma_{m}$ is the second level substitution elasticity. As we have only one good for use in each country, the price of basic domestic goods $p_{i}^{d}$ defines the purchase price of the good. These reflect CES sub-utility maximization and are given as:

$$
\begin{aligned}
& P_{i}^{m}=\left[\sum_{j \neq i} \kappa_{j}^{i}\left(p_{j}^{d}\right)^{1-\sigma_{m}}\right]^{\frac{1}{1-\sigma_{m}}} \\
& R_{j}^{i}=\frac{\kappa_{j}^{i} P_{i}^{m} M_{i}}{\left(p_{j}^{d}\right)^{\sigma_{m}} \sum_{j \neq i} \kappa_{j}^{i}\left(p_{j}^{d}\right)^{1-\sigma_{m}}}=\frac{\kappa_{j}^{i}\left(P_{i}^{m}\right)^{\sigma_{m}} M_{i}}{\left(p_{j}^{d}\right)^{\sigma_{m}}}
\end{aligned}
$$

The model can be amended to capture emission costs by treating them as a percentage loss of output in country: 


$$
\begin{aligned}
& I_{i}=p_{i}^{w}\left(R S_{i}-\varphi \frac{\overline{\Delta E_{i}}-\Delta E_{i}}{\overline{\Delta E_{i}}} R S_{i}\right)-B O T_{i}+T I_{i} \\
& T I_{i}=\sum_{j \neq i} t_{j} p_{j}^{w} R_{j}^{i} \\
& p_{i}^{d}=p_{i}^{w}\left(1+t_{i}\right) \\
& P_{i}^{m}=p\left(p_{1}^{d}, p_{2}^{d}, \ldots, p_{i-1}^{d}, p_{i+1}^{d}, \ldots, p_{N}^{d}\right)
\end{aligned}
$$

where $I_{i}$ is the income of country $i$, which is the sum of GDP, trade balance $B O T_{i}$ and tariff revenue $T I_{i} \cdot \varphi$ is an emission reduction cost factor which enlarges or reduces emission costs. $\overline{\Delta E_{i}}$ is the change in emissions along the BAU path; and $t_{i}$ is the tariff rate on good $i$.

The model also can be amended to capture financial transfers by treating them as aid to countries $i$, being negative if country $i$ is the source of transfers.

$$
I_{i}=p_{i}^{w}\left(R S_{i}-\varphi \frac{\overline{\Delta E_{i}}-\Delta E_{i}}{\overline{\Delta E_{i}}} R S_{i}\right)-B O T_{i}+F T_{i}
$$

The size of transfer, as a percentage of developing country's GDP or percentage of developed countries' GDP, or an exact amount transferred from developed countries is exogenous.

\subsection{Trade Equilibrium}

Given values of $\Delta R S_{i}$, a trade equilibrium is given by prices $p_{1}^{w}, \ldots, p_{N}^{w}$ for which global markets clear, i.e.

$$
\begin{aligned}
& \sum_{j \neq i} R_{i}^{j}+D_{i}=\Delta R S_{i} \quad(i=1 \ldots . N) \\
& \sum_{i} B O T_{i}=0
\end{aligned}
$$

Thus, in this structure, when countries contemplate participating in global 
environmental negotiations, if they reduce emissions by reducing GDP there will be general equilibrium implications for all prices and quantities. Importantly, tariffs and financial transfers will cause the price of their own good $i$ to change giving a terms of trade impact for the country making the emission reduction. This will spread the burden of the country emissions reduction to all other countries reducing the own country cost of emission reductions to the country making the reduction. This will, in turn, increase the willingness to participate in global emission reductions negotiations. 


\section{Model calibration}

We calibrate our model to a base case business as usual (BAU) scenario for the period 2006-2056 for the eight region country grouping, Brazil, Russia, India, China, US, EU, Japan, and ROW(the rest of the world).

We use GDP growth as a measure of potential change in consumption by country over the period. We first assume that country growth rates in the period 2000-2056 remain unchanged over the whole period of 50 years between 2006 and 2056. A cumulative trade pattern data is constructed by assuming that country's imports and exports both grow at the same rate as the BAU path. We firstly project China's imports and exports given its assumed 0.07 growth rate, and then omit it to calculate India's exports and imports with an assumed growth rate of 0.06 , and then Russia, Brazil, USA, EU, Japan and the rest of the world (Row) given assumed BAU trade growth rates of $0.06,0.04,0.02,0.015,0.015$ and 0.015 respectively (see table 1 ). By construction, the total world trade of balance is zero along the BAU.

We then calibrate a temperature change function for an assumed BAU temperature change over the period drawn from key literature sources, including Stern (2006) and Mendelsohn (2007) and preferences are determined for each country using alternative damage estimates for the same sources.

All the data for each time period are projected based on the data for 2006(Tables 1 and 2). We have three types of data: base case data in 2006, created cumulative trade pattern data for 2056 given BAU growth in trade, and cumulative trade pattern data relative to the base year (changes of cumulative trade pattern data). We also use a discount factor in modifying the effective growth rate for different timeframes and use a PPP measure of GDP in sensitivity analysis. 
Table 1 Bilateral Merchandise Trade of the Major Entities (2006) (billion \$)

\begin{tabular}{|c|c|c|c|c|c|c|c|c|c|}
\hline & $\begin{array}{c}\text { Brazil } \\
\text { Exp }\end{array}$ & $\begin{array}{c}\text { Russia } \\
\text { Exp }\end{array}$ & $\begin{array}{c}\text { India } \\
\text { Exp }\end{array}$ & $\begin{array}{c}\text { China } \\
\text { Exp }\end{array}$ & $\begin{array}{c}\text { U.S } \\
\text { Exp }\end{array}$ & $\begin{array}{c}\text { E.U. } \\
\text { Exp }\end{array}$ & $\begin{array}{c}\text { Japan } \\
\text { Exp }\end{array}$ & $\begin{array}{c}\text { Row } \\
\text { Exp }\end{array}$ & BOT \\
\hline Brazil Imp & 1025.89 & 0.77 & 1.53 & 7.67 & 19.94 & 23.01 & 3.16 & 39.79 & 41.58 \\
\hline Russia Imp & 3.77 & 846.29 & 1.15 & 16.06 & 8.03 & 75.22 & 9.67 & 49.98 & 140.65 \\
\hline India Imp & 1.05 & 2.97 & 966.40 & 14.86 & 10.32 & 30.95 & 4.55 & 110.15 & -54.59 \\
\hline China Imp & 12.91 & 17.55 & 10.28 & 2467.21 & 59.31 & 90.33 & 115.67 & 485.41 & 177.48 \\
\hline U.S. Imp & 28.04 & 20.74 & 22.99 & 305.81 & 14045.02 & 339.84 & 152.28 & 1049.74 & -881.15 \\
\hline E.U. Imp & 32.91 & 148.70 & 28.05 & 240.51 & 220.63 & 10852.57 & 95.88 & 931.13 & -216.15 \\
\hline Japan Imp & 5.09 & 6.66 & 4.06 & 118.59 & 69.46 & 59.87 & 4298.08 & 315.85 & 70.36 \\
\hline ROW Imp & 53.71 & 107.13 & 52.20 & 265.44 & 650.59 & 862.44 & 268.72 & 13960.45 & 721.82 \\
\hline
\end{tabular}

Notes: (1) The trade data for US, EU, Japan, and China are collected directly from website of WTO; (2) Data for India, Russia, and Brazil were calculated based on world data WTO website and proportion data from EUROSTAT; (3) The exports and imports of each pair of countries are not exactly the same, and we keep the import data of each country; (4) The export data of each country is the imports data of the trade partner.

Table 2 Bilateral Merchandise Trade of the Major Entities (2006) (billion \$) with BRICs as a whole

\begin{tabular}{|c|c|c|c|c|c|c|}
\hline & BRIC export & U.S Exp & E.U. Exp & Japan Exp & ROW Exp & BOT \\
\hline BRIC import & 5396.36 & 15768.625 & 12639.349 & 11479.851 & 23779.461 & 305.12 \\
\hline U.S. import & 14914.71 & 14045.019 & 339.839 & 152.279 & 1049.736 & -881.15 \\
\hline E.U. import & 11619.25 & 220.629 & 10852.568 & 95.883 & 931.13 & -216.149 \\
\hline Japan import & 4561.80 & 69.457 & 59.874 & 4298.078 & 315.854 & 70.357 \\
\hline ROW import & 2260.23 & 650.588 & 862.444 & 268.718 & 13960.45 & 721.822 \\
\hline
\end{tabular}

Notes: (1) The trade data for US, EU, Japan are collected directly from website of WTO; (2) Data for BRICs were calculated based on Table 1; (3) The exports and imports of each pair of countries are not exactly the same, and we keep the import data of each country; (4) The export data of each country is the imports data of the trade partner. 
Table 3 Total output and emission intensity data and projections to 2056

\begin{tabular}{|c|c|c|c|c|c|c|c|c|c|}
\hline & Brazil & Russia & India & China & U.S & E.U. & Japan & ROW & Total \\
\hline $\begin{array}{l}\text { Output } 2004 \\
\text { (Trillion) }\end{array}$ & 0.664 & 0.592 & 0.667 & 2.254 & 11.712 & 13.044 & 4.608 & 8.048 & - \\
\hline $\begin{array}{c}\text { Emission } 2004 \\
\text { (Billion Metric Tons) } \\
\end{array}$ & 0.332 & 1.525 & 1.343 & 5.009 & 6.050 & 3.841 & 1.258 & 7.880 & - \\
\hline Emission intensity 2004 & 0.500 & 2.577 & 2.012 & 2.222 & 0.517 & 0.294 & 0.273 & 0.979 & - \\
\hline Average growth rate & 0.04 & 0.06 & 0.06 & 0.07 & 0.02 & 0.015 & 0.015 & 0.015 & - \\
\hline $\begin{array}{c}\text { Average growth rate after } \\
\text { discount before } 2036\end{array}$ & 0.03 & 0.045 & 0.045 & 0.055 & 0.015 & 0.01 & 0.01 & 0.015 & - \\
\hline $\begin{array}{c}\text { Average growth rate after } \\
\text { discount for } 2037-2056\end{array}$ & 0.02 & 0.03 & 0.03 & 0.04 & 0.01 & 0.005 & 0.005 & 0.01 & - \\
\hline $\begin{array}{c}\text { Assumed PPP index } \\
\text { (base on } 2007 \text { by WB) }\end{array}$ & 1.40 & 1.60 & 2.50 & 2.10 & 1.00 & 0.85 & 0.95 & 1.35 & - \\
\hline $\begin{array}{l}\text { Output in } 2006 \\
\left(R S_{i}^{2006}\right)\end{array}$ & 1.067 & 0.987 & 0.912 & 2.645 & 13.164 & 10.636 & 4.368 & 14.682 & 48.46 \\
\hline $\begin{array}{l}\text { Emission in } 2006 \\
\left(\Delta E_{i}^{2006}\right)\end{array}$ & 0.53 & 2.54 & 1.83 & 5.88 & 6.81 & 3.13 & 1.19 & 14.37 & 36.29 \\
\hline $\begin{array}{c}\text { Accu. Output by } 2036 \\
\left(R S_{i}^{2036}\right)\end{array}$ & 33.63 & 62.22 & 58.64 & 244.22 & 176.30 & 112.05 & 48.58 & 179.39 & 915.03 \\
\hline $\begin{array}{c}\text { Accu. Output by } 2056 \\
\left(R S_{i}^{2056}\right)\end{array}$ & 130.83 & 298.86 & 281.40 & 1322.87 & 573.28 & 368.85 & 169.64 & 647.25 & 3792.98 \\
\hline $\begin{array}{l}\text { Accu. Output by } 2056 \\
\text { With PPP measure } \\
\left.\text { (PPP } R S_{i}^{2056}\right)\end{array}$ & 183.16 & 478.18 & 703.50 & 2778.03 & 573.28 & 313.52 & 161.16 & 874.15 & 6064.98 \\
\hline $\begin{array}{l}\text { Accu. Output by } 2056 \\
\text { with discount } \\
\text { (discount } R S_{i}^{2056} \text { ) }\end{array}$ & 52.31 & 93.94 & 88.42 & 435.93 & 280.78 & 140.48 & 63.57 & 359.62 & 1515.04 \\
\hline $\begin{array}{c}\text { Accu. Output by } 2086 \\
\left(R S_{i}^{2106}\right)\end{array}$ & 616.68 & 2065.93 & 1940.94 & 11450.25 & 2003.01 & 1423.52 & 779.82 & 3184.88 & 23465.04 \\
\hline $\begin{array}{l}\text { Accu. emis. By } 2036 \\
\left(\Delta E_{i}^{2036}\right)\end{array}$ & 16.82 & 160.34 & 117.99 & 542.65 & 91.15 & 32.94 & 13.26 & 175.63 & 1150.77 \\
\hline $\begin{array}{l}\text { Accu. emis. By } 2056 \\
\left(\Delta E_{i}^{2056}\right)\end{array}$ & 65.42 & 770.16 & 566.18 & 2939.42 & 296.39 & 108.44 & 46.31 & 633.92 & 5426.23 \\
\hline $\begin{array}{l}\text { Accu. Emis by } 2056 \text { with } \\
\text { PPP measure } \\
\left(\text { PPP } \Delta E_{i}^{2056}\right)\end{array}$ & 91.58 & 1232.26 & 1415.44 & 6172.78 & 296.39 & 92.18 & 44.00 & 855.79 & 10200.41 \\
\hline $\begin{array}{l}\text { Accu. emis. by } 2056 \\
\text { with discount } \\
\text { (Discount } \Delta E_{i}^{2056} \text { ) }\end{array}$ & 26.16 & 242.09 & 177.89 & 968.63 & 145.16 & 41.30 & 17.35 & 352.07 & 1970.65 \\
\hline $\begin{array}{l}\text { Accu. emis. by } 2086 \\
\left(\Delta E_{i}^{2106}\right)\end{array}$ & 308.34 & 5323.91 & 3905.17 & 25442.45 & 1035.56 & 418.52 & 212.89 & 3118.00 & 39764.83 \\
\hline
\end{tabular}

Notes: (1) GDP 2004 output data from the website of World Bank; (2) All the data for the different time periods in this table are obtained by deducting base year data. Emission data is total output data times emission intensity. We assume emission intensity does not change over the different timeframes. 
Table 4 Cumulative projected trade data by 2056 (trillion \$)

\begin{tabular}{|c|c|c|c|c|c|c|c|c|c|}
\hline & Brazil Exp & Russia Exp & India Exp & China Exp & U.S Exp & E.U. Exp & Japan Exp & ROW Exp & BOT \\
\hline Brazil Imp & 162.88 & 0.24 & 0.47 & 3.34 & 3.17 & 3.65 & 0.50 & 6.32 & 8.42 \\
\hline Russia Imp & 1.16 & 260.45 & 0.35 & 6.99 & 2.47 & 23.15 & 2.98 & 15.38 & 43.48 \\
\hline India Imp & 0.32 & 0.91 & 297.42 & 6.46 & 3.17 & 9.52 & 1.40 & 33.90 & -17.38 \\
\hline China Imp & 5.62 & 7.64 & 4.47 & 1073.20 & 25.80 & 39.29 & 50.32 & 211.14 & 77.20 \\
\hline U.S. Imp & 4.45 & 6.38 & 7.08 & 133.02 & 1211.68 & 29.32 & 13.14 & 90.56 & -168.18 \\
\hline E.U. Imp & 5.22 & 45.76 & 8.63 & 104.62 & 19.03 & 811.64 & 7.17 & 69.64 & -86.17 \\
\hline Japan Imp & 0.81 & 2.05 & 1.25 & 51.58 & 5.99 & 4.48 & 321.44 & 23.62 & 5.82 \\
\hline ROW Imp & 8.53 & 32.97 & 16.06 & 115.46 & 56.13 & 64.50 & 20.10 & 1044.08 & 136.82 \\
\hline
\end{tabular}

Notes: Cumulative trade pattern by 2056 data is constructed by assuming that country's import and export both grow at the same rate as the BAU path. We get China's import and export data first given 0.07 growth rate, and then omit it to calculate the India's export and import with a growth rate of 0.06 and so forth. We assume that the total world trade of balance is zero and in this table don't consider a discount factor

Table 5 Cumulative projected trade data by 2056 (trillion \$) with BRICs as a whole

\begin{tabular}{|c|c|c|c|c|c|c|}
\hline by 2056 trillion & BRIC export & U.S Exp & E.U. Exp & Japan Exp & ROW Exp & BOT \\
\hline BRIC import & 1831.92 & 34.61 & 75.62 & 55.19 & 266.74 & 111.72 \\
\hline U.S. import & 150.93 & 1211.68 & 29.32 & 13.14 & 90.56 & -168.18 \\
\hline E.U. import & 164.24 & 19.03 & 811.64 & 7.17 & 69.64 & -86.17 \\
\hline Japan import & 55.69 & 5.99 & 4.48 & 321.44 & 23.62 & 5.82 \\
\hline ROW import & 173.02 & 56.13 & 64.50 & 20.10 & 1044.08 & 136.82 \\
\hline
\end{tabular}

Note: Data for BRIC were calculated based on Table 4;

Table 6 Changes in cumulative projected trade data by 2056 (trillion \$) with 2006 as base year

\begin{tabular}{|c|c|c|c|c|c|c|c|c|c|}
\hline & Brazil Exp & Russia Exp & India Exp & China Exp & U.S Exp & E.U. Exp & Japan Exp & ROW Exp & BOT \\
\hline Brazil Imp & 111.59 & 0.20 & 0.40 & 2.95 & 2.17 & 2.50 & 0.34 & 4.33 & 6.34 \\
\hline Russia Imp & 0.97 & 218.14 & 0.30 & 6.18 & 2.07 & 19.39 & 2.49 & 12.88 & 36.44 \\
\hline India Imp & 0.27 & 0.77 & 249.10 & 5.72 & 2.66 & 7.98 & 1.17 & 28.39 & -14.65 \\
\hline China Imp & 4.97 & 6.76 & 3.96 & 949.84 & 22.84 & 34.78 & 44.53 & 186.87 & 68.33 \\
\hline U.S. Imp & 3.05 & 5.34 & 5.93 & 117.73 & 509.43 & 12.33 & 5.52 & 38.07 & -124.12 \\
\hline E.U. Imp & 3.58 & 38.33 & 7.23 & 92.59 & 8.00 & 269.01 & 2.38 & 23.08 & -75.36 \\
\hline Japan Imp & 0.55 & 1.72 & 1.05 & 45.65 & 2.52 & 1.48 & 106.54 & 7.83 & 2.30 \\
\hline ROW Imp & 5.84 & 27.61 & 13.45 & 102.19 & 23.60 & 21.38 & 6.66 & 346.05 & 100.72 \\
\hline
\end{tabular}

Notes: Taking 2006 as the base year, changes in the cumulative trade pattern by 2056 data are obtained by using the cumulative trade pattern given by 2056 data minus 50 times the 2006 data. 
Table 7 Changes in cumulative projected trade data by 2056 (trillion \$) with BRICs as a whole and 2006 as base year

\begin{tabular}{|c|c|c|c|c|c|c|}
\hline by 2056 trillion & BRIC export & U.S Exp & E.U. Exp & Japan Exp & ROW Exp & BOT \\
\hline BRIC import & 1562.10 & 29.73 & 64.64 & 48.54 & 232.48 & 96.46 \\
\hline U.S. import & 132.05 & 509.43 & 12.33 & 5.52 & 38.07 & -124.12 \\
\hline E.U. import & 141.73 & 8.00 & 269.01 & 2.38 & 23.08 & -75.36 \\
\hline Japan import & 48.97 & 2.52 & 1.48 & 106.54 & 7.83 & 2.30 \\
\hline ROW import & 149.10 & 23.60 & 21.38 & 6.66 & 346.05 & 100.72 \\
\hline
\end{tabular}

Note: Data for BRIC were calculated based on Table 6;

Table 8 Cumulative projected trade data by 2056 (trillion \$) adjusted with discount factor

\begin{tabular}{|c|c|c|c|c|c|c|c|c|c|}
\hline & Brazil Exp & Russia Exp & India Exp & China Exp & U.S Exp & E.U. Exp & Japan Exp & ROW Exp & BOT \\
\hline Brazil Imp & 96.32 & 0.10 & 0.20 & 1.36 & 1.87 & 2.16 & 0.30 & 3.74 & 4.43 \\
\hline Russia Imp & 0.49 & 110.80 & 0.15 & 2.84 & 1.05 & 9.85 & 1.27 & 6.54 & 18.48 \\
\hline India Imp & 0.14 & 0.39 & 126.53 & 2.63 & 1.35 & 4.05 & 0.60 & 14.42 & -7.36 \\
\hline China Imp & 2.28 & 3.10 & 1.82 & 436.36 & 10.49 & 15.98 & 20.46 & 85.85 & 31.39 \\
\hline U.S. Imp & 2.63 & 2.71 & 3.01 & 54.09 & 956.14 & 23.14 & 10.37 & 71.46 & -88.61 \\
\hline E.U. Imp & 3.09 & 19.47 & 3.67 & 42.54 & 15.02 & 647.03 & 5.72 & 55.51 & -34.86 \\
\hline Japan Imp & 0.48 & 0.87 & 0.53 & 20.97 & 4.73 & 3.57 & 256.25 & 18.83 & 4.74 \\
\hline ROW Imp & 5.04 & 14.03 & 6.83 & 46.95 & 44.29 & 51.42 & 16.02 & 950.38 & 71.78 \\
\hline
\end{tabular}

Notes: The same calculation method as the data construction in Table 6, but with different discount factor for two period 2006-2036 and 2036-2056, assumed that after 2036, economy growth rate a little bit slower than before.

Table 9 Changes in cumulative projected trade data by 2056 (trillion \$) adjusted with discount factor with 2006 as base year

\begin{tabular}{|c|c|c|c|c|c|c|c|c|c|}
\hline & Brazil Exp & Russia Exp & India Exp & China Exp & U.S Exp & E.U. Exp & Japan Exp & ROW Exp & BOT \\
\hline Brazil Imp & 45.03 & 0.06 & 0.12 & 0.97 & 0.88 & 1.01 & 0.14 & 1.75 & 2.35 \\
\hline Russia Imp & 0.31 & 68.49 & 0.09 & 2.04 & 0.65 & 6.09 & 0.78 & 4.04 & 11.45 \\
\hline India Imp & 0.08 & 0.24 & 78.21 & 1.89 & 0.83 & 2.50 & 0.37 & 8.91 & -4.63 \\
\hline China Imp & 1.64 & 2.23 & 1.30 & 313.00 & 7.52 & 11.46 & 14.67 & 61.58 & 22.52 \\
\hline U.S. Imp & 1.23 & 1.68 & 1.86 & 38.80 & 253.89 & 6.14 & 2.75 & 18.98 & -44.55 \\
\hline E.U. Imp & 1.44 & 12.03 & 2.27 & 30.51 & 3.99 & 104.40 & 0.92 & 8.96 & -24.05 \\
\hline Japan Imp & 0.22 & 0.54 & 0.33 & 15.04 & 1.26 & 0.58 & 41.35 & 3.04 & 1.22 \\
\hline ROW Imp & 2.36 & 8.67 & 4.22 & 33.68 & 11.76 & 8.30 & 2.58 & 252.36 & 35.69 \\
\hline
\end{tabular}

Notes: Taking 2006 as the base year, changes in the cumulative trade pattern by 2056 data adjusted with discount factor are obtained by using the cumulative trade pattern given by 2056 data adjusted with discount factor minus 50 times the 2006 data. 


\subsection{Calibration of parameters with real data}

We next turn to the calibration of preference parameters.

\subsubsection{Calibration of $\beta$ in utility function (equation (1))}

We begin with $\beta$ in the utility function (assumed the same across countries)

$$
U_{i}=U\left(R C_{i}, \Delta T\right)=R C_{i} *\left(\frac{C-\Delta T}{C}\right)^{\beta}
$$

According to the Stern Review (2005), Mendelssohn (2006) and other literature, the damage cost of emissions with BAU paths ranges from 1 to $20 \%$ of GDP out to 2050 , which we treat as a utility change of the same proportion and use it to calibrate the preference parameters. Without temperature change, the utility function is:

$$
U_{i}^{*}=R C_{i}
$$

And with damage we have :

$$
U_{i}^{*} / U_{i}=\left(\frac{C-\Delta T}{C}\right)^{\beta}
$$

With temperature change, there will be a loss from damage. The relative utility will be 1 minus the percentage the damage cost. We can calibrate $\beta$ with equation above and given different values of $\mathrm{C}$ given a time period of 50 years as the base case

yields Table 10 . When damage cost increases, $\beta_{\text {becomes bigger. Increasing the value }}$ of $\mathrm{C}$, the critical damage cost for $\beta=1.00$ becomes smaller.

In our simulation analysis, we use $\mathrm{C}=10$ as the base case, and do sensitivity analysis with $\mathrm{C}=20$ and $\mathrm{C}=30$. 
Table 10 Calibration of parameter $\beta$

\begin{tabular}{|c|c|c|c|c|}
\hline \multirow{21}{*}{ By 2056} & \multirow{7}{*}{ If $\mathrm{C}=10$} & $\alpha$ & 1-damage cost & $\beta$ \\
\hline & & 1 & 0.99 & 0.014 \\
\hline & & 1 & 0.90 & 0.152 \\
\hline & & 1 & 0.85 & 0.234 \\
\hline & & 1 & 0.80 & 0.322 \\
\hline & & 1 & 0.75 & 0.807 \\
\hline & & 1 & 0.50 & 1.000 \\
\hline & \multirow{7}{*}{ If $\mathrm{C}=20$} & $\alpha$ & 1-damage cost & $\beta$ \\
\hline & & 1 & 0.99 & 0.035 \\
\hline & & 1 & 0.95 & 0.178 \\
\hline & & 1 & 0.90 & 0.366 \\
\hline & & 1 & 0.85 & 0.565 \\
\hline & & 1 & 0.80 & 0.776 \\
\hline & & 1 & 0.75 & 1.000 \\
\hline & \multirow{7}{*}{ If $\mathrm{C}=30$} & $\alpha$ & 1-damage cost & $\beta$ \\
\hline & & 1 & 0.990 & 0.055 \\
\hline & & 1 & 0.900 & 0.578 \\
\hline & & 1 & 0.850 & 0.891 \\
\hline & & 1 & 0.840 & 0.956 \\
\hline & & 1 & 0.835 & 0.989 \\
\hline & & 1 & 0.833 & 1.000 \\
\hline
\end{tabular}

\subsubsection{Calibration of $a$ and $b$ in temperature change function}

The temperature change function is written as a function of emission changes. We treat it as a power function of total emission change (not output) of the world:

$$
\Delta T=a\left(\sum_{i} \Delta E_{i}\right)^{b}
$$

Based on the results from Stern Review (2005), the BAU path of emissions will lead to about 3 degree temperature increases around the year 2035, and near 5 degree C by around 2050. For simplification, we assume that zero growth in the global economy will lead to no temperature change.

With the data on growth rates and emission intensities for each relevant country, we can calibrate the parameters $a$ and $b$. We have the data for year 2006 and simulation data for 2036 and 2056. For simplicity, we choose 2006 as the base year, and assume that 30 years later, that is by 2036 , the global average temperature will increase 3 degrees, and 5 degrees by 2056. We assume that the BAU path implies output growth for each country slightly lower than that of 2000-2006, while emission 
intensities are unchanged from 2006.

We use a three point calibration based on equations (20):

$$
\begin{gathered}
0=a(36.2874)^{b} \\
\Delta T^{2036}=a(1150.78)^{b} \\
\Delta T^{2056}=a(5426.24)^{b}
\end{gathered}
$$

This gives different results for $\mathrm{a}$ and $\mathrm{b}$ given different BAU temperature changes,

Table 11 Calibration results for parameters $a$ and $b$

\begin{tabular}{|l|c|c|}
\hline & $\mathrm{a}$ & 0.294 \\
$\Delta T^{2036}=3$ & $\mathrm{~b}$ & 0.329 \\
\cline { 2 - 3 } & \multicolumn{2}{|c|}{$T^{2056}=5$}
\end{tabular}




\section{Model Experiments Results}

\subsection{Trade sanctions}

We first analyze the effects of trade sanctions (tariffs) on participation decisions. We evaluate the welfare impacts on countries of the discrete choice of participating and facing no sanction, or not participating. Countries will join only when the tariff makes their welfare level lower than that of taking on reduction commitments.

Table 12 present results for individual countries. For Brazil if the tariff used by all other countries against Brazil is smaller than $240 \%$, Brazil is not willing to join the agreement. With the increased tariff, by avoiding this joint action, Brazil benefits more. But the effectiveness of these measures also depends on who uses tariffs against Brazil. If only developed countries (US, EU and Japan) are involved, only thousands percent or more tariffs can induce Brazil's participation. If developing countries like India, Russia, China and others also jointly take action, a smaller tariff of $240 \%$ can suffice. Russia and China provide similar results to Brazil. For Russia, if all other countries use tariffs against her to participate, $75 \%$ is enough, but $240 \%$ needed if only used by the developed countries (US, EU and Japan). The tariff needed to induce China's participation is $259.3 \%$ if used by all other countries, and almost $922 \%$, if only used by developed countries. If the developing country is a net importer, like India, the tariff has no effect on her. Compared with the net exporters, like China, Russia and Brazil, India presents a different story.

Taking the BRICs as a whole, in Table 13, a 383\% tariff by all non BRIC regions can induce the BRICs' to join the agreement. If only used by developed country, a tariff of more than $1150 \%$ is needed. 
Table 12: Impacts of tariffs against all developing countries on their non participation (Hicksian CV in US\$ trillion)

\begin{tabular}{|c|c|c|}
\hline Tariff & $\begin{array}{l}\text { Brazil's welfare change from participation and } \\
\text { avoiding joint tariff by all non Brazil regions }\end{array}$ & $\begin{array}{l}\text { Brazil's welfare change from participation and } \\
\text { avoiding joint tariff by US, EU, Japan only }\end{array}$ \\
\hline $0 \%$ & -4.746 & -4.746 \\
\hline $50 \%$ & -3.584 & -4.386 \\
\hline $100 \%$ & -2.172 & -4.165 \\
\hline $240 \%$ & 0.024 & -3.835 \\
\hline $6370 \%$ & 5.122 & 0.020 \\
\hline Tariff & $\begin{array}{l}\text { Russia's welfare change from participation and } \\
\text { avoiding joint tariff by all non Russia regions }\end{array}$ & $\begin{array}{l}\text { Russia's welfare change from participation and } \\
\text { avoiding joint tariff by US, EU, Japan only }\end{array}$ \\
\hline $0 \%$ & -8.436 & -8.436 \\
\hline $50 \%$ & -2.657 & -5.683 \\
\hline $75 \%$ & 0.007 & -4.646 \\
\hline $150 \%$ & 7.423 & -2.319 \\
\hline $270 \%$ & 18.170 & 0.042 \\
\hline Tariff & $\begin{array}{l}\text { China's welfare changes from participation and } \\
\text { avoiding joint tariff by all non china regions }\end{array}$ & $\begin{array}{l}\text { China's welfare changes from participation and } \\
\text { avoiding joint tariff by US, EU, Japan only }\end{array}$ \\
\hline $0 \%$ & -24.423 & -24.423 \\
\hline $50 \%$ & -18.357 & -20.681 \\
\hline $259.3 \%$ & 0.006 & -11.449 \\
\hline $900 \%$ & 35.723 & -0.218 \\
\hline $922 \%$ & 36.720 & 0.004 \\
\hline Tariff & $\begin{array}{l}\text { India's welfare change from participation and } \\
\text { avoiding joint tariff by all non India regions }\end{array}$ & $\begin{array}{l}\text { India's welfare change from participation and } \\
\text { avoiding joint tariff by US, EU, Japan only }\end{array}$ \\
\hline $0 \%$ & -8.955 & -8.955 \\
\hline $50 \%$ & -10.518 & -9.571 \\
\hline $100 \%$ & -12.778 & -10.203 \\
\hline
\end{tabular}

Note: (1) Given 10\% damage cost. (2) Assumed 50\% emission cut globally. (3) The timeframe is to 2056, and with temperature change 5 degree.

Table 13: Impacts of tariffs against BRIC as a whole on its non participation

\begin{tabular}{||c|c|c||}
\hline Tariff & $\begin{array}{c}\text { BRIC's welfare change from participation and } \\
\text { avoiding joint tariff by non-BRIC regions } \\
\text { (Hicksian CV in US\$ trillion) }\end{array}$ & $\begin{array}{c}\text { BRIC's welfare change from participation and } \\
\text { avoiding joint tariff by US, EU, Japan only } \\
\text { (Hicksian CV in US\$ trillion) }\end{array}$ \\
\hline $0 \%$ & -34.366 & -34.366 \\
\hline $50 \%$ & -27.918 & -29.721 \\
\hline $250 \%$ & -9.399 & -18.375 \\
\hline $383 \%$ & $\mathbf{0 . 0 1 0}$ & -13.666 \\
\hline $500 \%$ & 7.301 & -10.451 \\
\hline $1150 \%$ & 39.505 & $\mathbf{0 . 0 7 6}$ \\
\hline
\end{tabular}

Note: (1) Given 10\% damage cost. (2) Assumed 50\% emission cut globally. (3) The timeframe is to 2056, and with temperature change 5 degree. 


\subsection{Financial transfers}

We next consider the impact of conditional financial transfers on country participation decisions. We assume that only the EU, US, and Japan make such transfers. Recipient countries have an incentive to join the agreement only when they get compensation from EU, US and Japan, which covers losses from taking on reduction targets.

From Tables 14-17, we find that, given an assumed 10\% damage cost, if the transfer from developed countries to developing country is small and less than $3 \%$ of the country's GDP, BRICs may have no willingness to join the agreement. Only when transfers are large enough (6.3 US\$trillion or almost 5\% Brazil GDP to Brazil, 13.5 US\$trillion or 4.8\% Russia GDP to Russia, 12.9 US\$trillion or $4.8 \%$ India GDP to India, and 45 US\$trillion or 3.6\% Chinese GDP to China), do these countries have an incentive. In term of transferring countries' (US, EU, Japan) GDP level, each needs to transfer almost 5\% GDP to China, $1.22 \%$ GDP to India, $1.28 \%$ GDP to Russia, or $0.6 \%$ GDP to Brazil to encourage their participation.

The size of transfers also depends on how large the damage cost of temperature change is. If the damage cost is very large, a small transfer will induce developing country to join.

The timeframe to achieve the transfer by developing countries also influences the participation decision. The earlier they get the financial transfer, the smaller the transfer they need to join the agreement. 
Table 14: Size of Financial Transfers needed to encourage Brazil's participation

\begin{tabular}{|c|c|c|c|c|}
\hline & \multicolumn{3}{|c|}{$\begin{array}{l}\text { Brazil's welfare changes with different damage cost } \\
\text { (Hicksian CV in US\$ trillion) }\end{array}$} \\
\hline & & $5 \%$ & $10 \%$ & $20 \%$ \\
\hline \multirow{4}{*}{$\begin{array}{l}\text { Total size of } \\
\text { transfer to China } \\
\text { over } 50 \text { years } \\
(\$ \text { trillion })\end{array}$} & $\begin{array}{c}1.5 \\
(1.21 \% \text { India GDP })\end{array}$ & -5.074 & -5.329 & -5.927 \\
\hline & $\begin{array}{c}3 \\
(2.41 \% \text { India GDP })\end{array}$ & -3.496 & -3.662 & -4.053 \\
\hline & $\begin{array}{c}6.3 \\
(5.07 \% \text { India GDP })\end{array}$ & -0.021 & 0.004 & 0.072 \\
\hline & $\begin{array}{c}15 \\
(5.6 \% \text { India GDP) }\end{array}$ & 9.135 & 9.669 & 10.941 \\
\hline \multirow{3}{*}{$\begin{array}{c}\text { Transfer } \\
\text { proportional to US, } \\
\text { EU and Japan's } \\
\text { individual GDP } \\
\text { over } 50 \text { years }\end{array}$} & $\begin{array}{c}\text { Each } 0.5 \% \\
\text { (US: } 2.72, \text { EU } 1.75, \text { Jap 0.81) }\end{array}$ & -1.095 & -1.129 & -1.204 \\
\hline & $\begin{array}{c}\text { Each 0.6\% } \\
\text { (US: 5.44, EU 3.50, Jap 1.60) }\end{array}$ & 0.011 & 0.037 & 0.110 \\
\hline & $\begin{array}{c}\text { Each 1\% } \\
\text { (US: 6.64, EU 4.31, Jap 1.98) }\end{array}$ & 4.463 & 4.738 & 5.394 \\
\hline \multirow{3}{*}{$\begin{array}{l}\text { Change period of } \\
\text { analysis to }\end{array}$} & 30 years & 16.212 & 17.428 & 20.400 \\
\hline & 50 years & 9.135 & 9.669 & 10.941 \\
\hline & 80 years & -106.302 & -103.926 & -98.923 \\
\hline
\end{tabular}

Note: (1) Assumed 50\% emission cut globally. (2) Given temperature change by 2056 is 5 degree. (3) Financial transfer only from developed countries US, EU and Japan to developing countries. ( 4 ) Change period of analysis is with assumed 15 trillion transferred from developed country to the country.

Table 15: Size of Financial Transfers needed to encourage Russia participation

\begin{tabular}{|c|c|c|c|c|}
\hline & & \multicolumn{3}{|c|}{$\begin{array}{l}\text { Russia's welfare changes with different damage cost } \\
\text { (Hicksian CV in US\$ trillion) }\end{array}$} \\
\hline & & $5 \%$ & $10 \%$ & $20 \%$ \\
\hline \multirow{4}{*}{$\begin{array}{l}\text { Total size of } \\
\text { transfer to China } \\
\text { over } 50 \text { years } \\
\text { (\$ trillion })\end{array}$} & $\begin{array}{c}3 \\
(1.1 \% \text { Russia GDP }) \\
\end{array}$ & -11.157 & -11.117 & -10.895 \\
\hline & $\begin{array}{c}9 \\
(3.3 \% \text { Russia GDP) } \\
\end{array}$ & -5.074 & -4.703 & -3.695 \\
\hline & $\begin{array}{c}13.5 \\
(4.8 \% \text { Russia GDP })\end{array}$ & -0.510 & 0.110 & 1.709 \\
\hline & $\begin{array}{c}15 \\
(5.6 \% \text { Russia GDP) }\end{array}$ & 1.011 & 1.715 & 3.511 \\
\hline \multirow{4}{*}{$\begin{array}{c}\text { Transfer } \\
\text { proportional to US, } \\
\text { EU and Japan's } \\
\text { individual GDP } \\
\text { over } 50 \text { years }\end{array}$} & $\begin{array}{c}\text { Each 0.5\% } \\
\text { (US: } 2.72, \text { EU } 1.75, \text { Jap 0.81) }\end{array}$ & -8.842 & -8.676 & -8.153 \\
\hline & $\begin{array}{c}\text { Each 1\% } \\
\text { (US: 5.44, EU 3. 5, Jap 1.6) }\end{array}$ & -3.482 & -3.023 & -1.808 \\
\hline & $\begin{array}{c}\text { Each } 1.28 \% \\
\text { (US: } 6.97, \text { EU 4.49, Jap 2.06) }\end{array}$ & -0.477 & 0.145 & 1.748 \\
\hline & $\begin{array}{c}\text { Each } 1.5 \% \\
\text { (US: } 8.17, \text { EU 5.26, Jap 2.42) }\end{array}$ & 1.889 & 2.640 & 4.549 \\
\hline \multirow{3}{*}{$\begin{array}{l}\text { Change period of } \\
\text { analysis to }\end{array}$} & 30 years & 9.666 & 10.398 & 12.191 \\
\hline & 50 years & 1.011 & 1.715 & 3.511 \\
\hline & 80 years & -853.336 & -848.648 & -837.542 \\
\hline
\end{tabular}

Note: (1) Assumed 50\% emission cut globally. (2) Given temperature change by 2056 is 5 degree. (3) Financial transfer only from developed countries US, EU and Japan to developing countries.( 4 )Change period of analysis is with assumed 15 trillion transferred from developed country to the country. 
Table 16: Size of Financial Transfers needed to encourage India's participation

\begin{tabular}{|c|c|c|c|c|}
\hline & \multicolumn{3}{|c|}{$\begin{array}{l}\text { India's welfare changes with different damage cost } \\
\text { (Hicksian CV in US\$ trillion) }\end{array}$} \\
\hline & & $5 \%$ & $10 \%$ & $20 \%$ \\
\hline \multirow{4}{*}{$\begin{array}{l}\text { Total size of } \\
\text { transfer to China } \\
\text { over } 50 \text { years } \\
\text { (\$ trillion) }\end{array}$} & $\begin{array}{c}3 \\
(1.1 \% \text { India GDP })\end{array}$ & -11.496 & -11.570 & -11.635 \\
\hline & $\begin{array}{c}9 \\
(3.3 \% \text { India GDP })\end{array}$ & -4.757 & -4.466 & -3.662 \\
\hline & $\begin{array}{c}12.9 \\
(4.8 \% \text { India GDP })\end{array}$ & -0.379 & 0.152 & 1.520 \\
\hline & $\begin{array}{c}15 \\
(5.6 \% \text { India GDP }) \\
\end{array}$ & 1.979 & 2.637 & 4.310 \\
\hline \multirow{4}{*}{$\begin{array}{c}\text { Transfer } \\
\text { proportional to US, } \\
\text { EU and Japan's } \\
\text { individual GDP } \\
\text { over } 50 \text { years }\end{array}$} & $\begin{array}{c}\text { Each } 0.5 \% \\
\text { (US: } 2.72, \text { EU } 1.75, \text { Jap 0.81) }\end{array}$ & -8.943 & -8.878 & -8.614 \\
\hline & $\begin{array}{c}\text { Each 1\% } \\
\text { (US: 5.44, EU 3. 5, Jap 1.6) }\end{array}$ & -3.020 & -2.634 & -1.606 \\
\hline & $\begin{array}{c}\text { Each } 1.22 \% \\
\text { (US: } 6.64, \text { EU 4.31, Jap 1.98) }\end{array}$ & -0.420 & 0.110 & 1.473 \\
\hline & $\begin{array}{c}\text { Each 1.5\% } \\
\text { (US: 8.17, EU 5.26, Jap 2.42) }\end{array}$ & 2.911 & 3.621 & 5.414 \\
\hline \multirow{3}{*}{$\begin{array}{l}\text { Change period of } \\
\text { analysis to }\end{array}$} & 30 years & 12.343 & 13.340 & 15.802 \\
\hline & 50 years & 1.979 & 2.637 & 4.310 \\
\hline & 80 years & -699.568 & -668.914 & -605.644 \\
\hline
\end{tabular}

Note: (1) Assumed 50\% emission cut globally. (2) Given temperature change by 2056 is 5 degree. (3) Financial transfer only from developed countries US, EU and Japan to developing countries. ( 4 ) Change period of analysis is with assumed 15 trillion transferred from developed country to the country.

Table 17: Size of Financial Transfers needed to encourage Chinese participation

\begin{tabular}{|c|c|c|c|c|}
\hline & \multicolumn{3}{|c|}{$\begin{array}{l}\text { China's welfare changes with different damage cost } \\
\text { (US\$ trillion) }\end{array}$} \\
\hline & & $5 \%$ & $10 \%$ & $20 \%$ \\
\hline \multirow{4}{*}{$\begin{array}{l}\text { Total size of } \\
\text { transfer to China } \\
\text { over } 50 \text { years } \\
(\$ \text { trillion })\end{array}$} & $\begin{array}{c}3 \\
(0.24 \% \text { Chinese GDP })\end{array}$ & -54.436 & -46.150 & -24.546 \\
\hline & $\begin{array}{c}15 \\
(1.19 \% \text { Chinese GDP })\end{array}$ & -41.918 & -33.022 & -9.990 \\
\hline & $\begin{array}{c}30 \\
(2.39 \% \text { Chinese GDP })\end{array}$ & -26.266 & -16.612 & 8.203 \\
\hline & $\begin{array}{c}45.3 \\
(3.6 \% \text { Chinese GDP) }\end{array}$ & -10.304 & 0.126 & 26.763 \\
\hline \multirow{5}{*}{$\begin{array}{c}\text { Transfer } \\
\text { proportional to US, } \\
\text { EU and Japan's } \\
\text { individual GDP } \\
\text { over } 50 \text { years }\end{array}$} & $\begin{array}{c}\text { Each 0.5\% } \\
\text { (US: } 2.72, \text { EU } 1.75, \text { Jap 0.81) } \\
\end{array}$ & -52.055 & -43.651 & -21.770 \\
\hline & $\begin{array}{c}\text { Each 1\% } \\
\text { (US: 5.44, EU 3. 5, Jap 1.6) }\end{array}$ & -46.544 & -37.869 & -15.355 \\
\hline & $\begin{array}{c}\text { Each 3\% } \\
\text { (US: } 16.3, \text { EU 10.5, Jap 4.8) }\end{array}$ & -24.498 & -14.743 & 10.312 \\
\hline & $\begin{array}{c}\text { Each 5\% } \\
\text { (US: 27.2, EU 17.5, Jap 8.1) }\end{array}$ & -2.439 & 8.394 & 35.989 \\
\hline & $\begin{array}{c}\text { Each 7.5\% } \\
\text { (US: 40.8, EU 26.3, Jap 12.1) }\end{array}$ & 25.689 & 38.145 & 69.599 \\
\hline \multirow{3}{*}{$\begin{array}{l}\text { Change period of } \\
\text { analysis to }\end{array}$} & 30 years & 5.929 & 7.096 & 10.143 \\
\hline & 50 years & -41.918 & -33.022 & -9.990 \\
\hline & 80 years & -509.888 & -349.677 & -162.433 \\
\hline
\end{tabular}

Note: (1) Assumed 50\% emission cut globally. (2) Given temperature change by 2056 is 5 degree. (3) Financial transfer only from developed countries US, EU and Japan to developing countries.( 4 )Change period of analysis is 
with assumed 15 trillion transferred from developed country to the country.

From Table 18, we find that developed countries make transfers to one country may lead to other developing countries being better off. And in some cases (transfers to China), financial transfers not only increase developing countries' welfare, but developed countries themselves as well due to the emission reduction effect.

Table 18: Impacts of financial transfer to a country on other regions welfare (Hicksian CV in US\$ trillion)

\begin{tabular}{|c|c|c|c|c|}
\hline & $\begin{array}{c}\text { US\$3 trillion } \\
\text { transfer to Brazil }\end{array}$ & $\begin{array}{c}\text { US\$3 trillion } \\
\text { transfer to Russia }\end{array}$ & $\begin{array}{c}\text { US\$3 trillion } \\
\text { transfer to India }\end{array}$ & $\begin{array}{c}\text { US\$3 trillion } \\
\text { transfer to China }\end{array}$ \\
\hline Brazil & $(-3.662)$ & 0.560 & 0.407 & 2.022 \\
\hline Russia & 0.019 & $(-11.117)$ & 0.747 & 4.159 \\
\hline India & 0.162 & 1.466 & $(-11.570)$ & 5.120 \\
\hline China & 0.346 & 5.722 & 4.103 & $(-46.150)$ \\
\hline US & $\mathbf{- 0 . 6 5 4}$ & 2.521 & 1.792 & 10.154 \\
\hline EU & $\mathbf{- 0 . 8 6 3}$ & 1.122 & 0.691 & 6.344 \\
\hline Japan & $\mathbf{- 1 . 0 3 6}$ & $\mathbf{- 0 . 3 1 4}$ & $\mathbf{- 0 . 5 2 4}$ & 1.697 \\
\hline others & $\mathbf{- 0 . 0 1 4}$ & 2.279 & 1.449 & 8.066 \\
\hline
\end{tabular}

Note: (1) Given 10\% damage cost. (2) Assumed 50\% emission cut globally. (3) Given temperature change by 20565 degree. (4) Financial transfer only from developed country US, EU and Japan to developing countries. 


\subsection{Sensitivity analysis}

We next consider the impact of model assumptions on country participation decisions.

In Tables 19, with tariffs as sanctions, different trade elasticities have different impacts on BRICs' participation decisions. Across the countries, compared to Russia and Brazil, China is more sensitive to trade elasticities. The larger the substitution between domestic goods and imported goods (keeping the second-level substitution elasticity unchanged $\sigma_{m}=0.9, \sigma$ increases from 0.5 to 1.2), the more the willingness to join the agreement. The more the substitution elasticity among different imported goods (keeping the first-level substitution elasticity $\sigma=0.5$ unchanged, $\sigma_{m}$ increase from 0.5 to 0.9 ), the more incentive for China to take on commitments. When taking financial transfers as the measure for encouraging participation, in Table 20, the substitution elasticity between traded goods in BRIC countries does not have much impact on country's participation decision.

BRICs are also insensitive to the temperature change upper-bound $\mathrm{C}$. The increases in $\mathrm{C}$ only changes the tariff threshold and financial transfer threshold a little.

But the size of the emission reduction cost $\varphi$, (changes from 1 to 0.01 ), does influence the country's participation decision. When the reduction cost is low, $\varphi=0.01$ (nearly zero reduction cost), most BRIC countries are willing to join the agreement. But with larger reduction cost of $\varphi=1$, only large tariffs and financial transfer encourage participation.

We also vary the discount factor we assume. In this case, the benefit from avoiding tariffs and from receiving financial transfers both increase for all BRIC countries compared to the no discount case. Smaller tariffs or financial transfers will induce participation. 
When considering PPP measures of GDP, we find that both the tariff threshold and the size of financial transfer increase compared to the non-PPP case.

Table 19 Sensitivity of threshold tariffs by all countries

to key model parameters

\begin{tabular}{|c|c|c|c|c|}
\hline & & $\begin{array}{c}\text { Brazil's tariff } \\
\text { threshold under } \\
\text { different parameter }\end{array}$ & \begin{tabular}{|c|} 
Russia's tariff \\
threshold under \\
different parameter
\end{tabular} & $\begin{array}{c}\text { China's tariff } \\
\text { threshold under } \\
\text { different parameter }\end{array}$ \\
\hline \multirow{3}{*}{$\begin{array}{c}\text { Changing trade } \\
\text { elasticity } \\
\sigma, \sigma_{m}\end{array}$} & $\begin{array}{c}\sigma=0.5 \\
\sigma_{m}=0.5\end{array}$ & $238 \%$ & $72 \%$ & $133.1 \%$ \\
\hline & $\begin{array}{c}\sigma=0.5 \\
\sigma_{m}=0.9\end{array}$ & $240 \%$ & $75 \%$ & $259.3 \%$ \\
\hline & $\begin{array}{c}\sigma=1.2 \\
\sigma_{m}=0.9 \\
\end{array}$ & $235 \%$ & $71 \%$ & $160 \%$ \\
\hline \multirow{3}{*}{$\begin{array}{l}\text { Varied temperature } \\
\text { change up-bound } \\
\text { (C) }\end{array}$} & 10 & $240 \%$ & $75 \%$ & $259.3 \%$ \\
\hline & 20 & $242 \%$ & $76 \%$ & $278 \%$ \\
\hline & 30 & $242 \%$ & $76 \%$ & $282 \%$ \\
\hline \multirow{3}{*}{$\begin{array}{l}\text { Changing reduction } \\
\text { cost factor } \\
(\varphi)\end{array}$} & 1 & $7500 \%$ & $9800 \%$ & $6500 \%$ \\
\hline & 0.1 & $240 \%$ & $75 \%$ & $259.3 \%$ \\
\hline & 0.01 & $0 \%$ & $0 \%$ & $0 \%$ \\
\hline \multirow{2}{*}{$\begin{array}{c}\text { Use of PPP } \\
\text { measure for China } \\
\text { (based on } 2007 \text { PPP } \\
\text { GDP by WB) }\end{array}$} & $\begin{array}{l}\text { Without } \\
\text { PPP }\end{array}$ & $240 \%$ & $75 \%$ & $259.3 \%$ \\
\hline & With PPP & $420 \%$ & $132 \%$ & $508 \%$ \\
\hline \multirow{2}{*}{$\begin{array}{c}\text { Assumed discount } \\
\text { factor in DPV } \\
\text { calculation of GDP }\end{array}$} & $\begin{array}{l}\text { without } \\
\text { discount }\end{array}$ & $240 \%$ & $75 \%$ & $259.3 \%$ \\
\hline & $\begin{array}{c}\text { With } \\
\text { discount }\end{array}$ & $35 \%$ & $38 \%$ & $190 \%$ \\
\hline
\end{tabular}


Table 20 Sensitivity of threshold financial transfers from developed country

to key model parameters

\begin{tabular}{|c|c|c|c|c|c|}
\hline & & $\begin{array}{l}\text { Financial transfer to } \\
\text { Brazil under } \\
\text { different parameters } \\
\text { (US\$ trillion) }\end{array}$ & $\begin{array}{l}\text { Financial transfer to } \\
\text { Russia under } \\
\text { different parameters } \\
\text { (US\$ trillion) }\end{array}$ & $\begin{array}{c}\text { Financial transfer to } \\
\text { India under different } \\
\text { parameters } \\
\text { (US\$ trillion) }\end{array}$ & $\begin{array}{c}\text { Financial transfer to } \\
\text { China under different } \\
\text { parameters } \\
\text { (US\$ trillion) }\end{array}$ \\
\hline \multirow{3}{*}{$\begin{array}{c}\text { Changing trade } \\
\text { elasticity } \\
\sigma, \sigma_{m}\end{array}$} & $\begin{array}{c}\sigma=0.5 \\
\sigma_{m}=0.5\end{array}$ & 6.15 & 13.2 & 12.60 & 44.4 \\
\hline & $\begin{array}{c}\sigma=0.5 \\
\sigma_{m}=0.9\end{array}$ & 6.30 & 13.5 & 12.80 & 45.3 \\
\hline & $\begin{array}{c}\sigma=1.2 \\
\sigma_{m}=0.9\end{array}$ & 6.24 & 13.35 & 12.75 & 45.0 \\
\hline \multirow{3}{*}{$\begin{array}{l}\text { Varied temperature } \\
\text { change up-bound }(\mathrm{C})\end{array}$} & 10 & 6.3 & 13.5 & 12.80 & 45.3 \\
\hline & 20 & 6.3 & 13.7 & 12.84 & 46.7 \\
\hline & 30 & 6.3 & 13.9 & 12.90 & 48.0 \\
\hline \multirow{3}{*}{$\begin{array}{l}\text { Changing reduction } \\
\text { cost factor } \\
(\varphi)\end{array}$} & 1 & 40.65 & 90.9 & 98.10 & 392.4 \\
\hline & 0.1 & 6.3 & 13.5 & 12.80 & 45.3 \\
\hline & 0.01 & 0.6 & 0 & 0.3 & 0 \\
\hline \multirow{2}{*}{$\begin{array}{c}\text { Use of PPP measure } \\
\text { for China } \\
\text { (based on } 2007 \text { PPP } \\
\text { GDP by WB) }\end{array}$} & $\begin{array}{l}\text { Without } \\
\text { PPP }\end{array}$ & 6.3 & 13.5 & 12.80 & 45.3 \\
\hline & With PPP & 9.3 & 20.7 & 21.00 & 73.2 \\
\hline \multirow{2}{*}{$\begin{array}{l}\text { Assumed discount } \\
\text { factor in DPV } \\
\text { calculation of GDP }\end{array}$} & $\begin{array}{l}\text { without } \\
\text { discount }\end{array}$ & 6.3 & 13.5 & 12.80 & 45.3 \\
\hline & $\begin{array}{c}\text { With } \\
\text { discount }\end{array}$ & 1.65 & 3.0 & 5.4 & 13.5 \\
\hline
\end{tabular}




\section{Concluding remarks}

In this paper, we discuss the participation of Brazil, Russia, India and China (BRIC) in global environmental negotiations.

Our result shows that these countries either singly or collectively will not enter negotiations unless damages from climate change are dramatic. Trade sanctions can induce developing countries participation in global environmental negotiations, but these are only effective when the non OECD country is a net exporter, as with China, Russia and Brazil or BRICs as a whole. The effect of trade sanctions also depends on many factors, such as who imposes the tariff, how long is the timeframe, trade elasticities, discount rate, PPP measures, and temperature change threshold etc.. The balance of results however indicate that compliance inducing tariffs would need to be very large (many hundreds of percent).

The results also show that financial transfers from developed countries to developing countries can encourage developing countries' joining in the agreement but the transfers would need to be large: the larger of the transfer, the more likelihood that commitments will be made. But the larger the damage from climate change, the smaller the tariff or financial transfer needed to induce participation. 
Biography:

Gerard Debreu and Scarf Herbert, 1963, "A Limit Theorem on the core of an Economy", International Economic Review, Vol. 4, No.3.

Herbert E. Scarf, 1967, “The Core of an N Person Game”, Econometrics, Vol.35, No.1.

Huifang, Tian and John Whalley, 2008, "China's Participation in global environmental negotiations", NBER Working Paper 14460, http://www.nber.org/papers/w14460.

H. Uzawa, 1999, "Global Warming as a Cooperative Game", Environmental Economics and Policy Studies", 1999, Vol.2.

H. Uzawa, 2003, “Economic Theory and Global Warming”, Cambridge University Press.

John Whalley, 1985, "Trade liberalization among major world trading areas", MIT Press, Cambridge, Massachusetts.

Lloyd S. Shapley, Martin Shubik, 1969, "On the Core of an Economic System with Externalities”, American Economic Review, Vol. 59, No. 4.

Nicholas H. Stern, 2006, "Stern Review on the Economics of Climate Change", London, UK: Her Majesty's Treasury.

Robert O. Mendelsohn, 2006, “A Critique of the Stern Report”, Regulation, Vol 29, No.4, Winter 2006-2007.

Scott Barrett, 1994, "Self-Enforcing International Environmental Agreements", Oxford Economic Papers, New Series, Vol. 46, Special Issue on Environmental Economics.

Yuezhou Cai, Raymond Riezman and John Whalley, 2009, "International trade and the negotiability of global climate change agreements", NBER working paper 14711, http://www.nber.org/papers/w14711 


\section{CESifo Working Paper Series}

for full list see www.cesifo-group.org/wp

(address: Poschingerstr. 5, 81679 Munich, Germany, office@cesifo.de)

2637 Shoshana Grossbard, How “Chicagoan” are Gary Becker's Economic Models of Marriage?, May 2009

2638 Roland Strausz, Regulatory Risk under Optimal Incentive Regulation, May 2009

2639 Holger Zemanek, Ansgar Belke and Gunther Schnabl, Current Account Imbalances and Structural Adjustment in the Euro Area: How to Rebalance Competitiveness, May 2009

2640 Harald Hau and Marcel Thum, Subprime Crisis and Board (In-)Competence: Private vs. Public Banks in Germany, May 2009

2641 Martin Halla, Mario Lackner and Friedrich G. Schneider, An Empirical Analysis of the Dynamics of the Welfare State: The Case of Benefit Morale, May 2009

2642 Balázs Égert, Infrastructure Investment in Network Industries: The Role of Incentive Regulation and Regulatory Independence, May 2009

2643 Christian Gollier, Expected Net Present Value, Expected Net Future Value, and the Ramsey Rule, May 2009

2644 Sören Blomquist and Håkan Selin, Hourly Wage Rate and Taxable Labor Income Responsiveness to Changes in Marginal Tax Rates, May 2009

2645 Dominique Demougin, Oliver Fabel and Christian Thomann, Implicit vs. Explicit Incentives: Theory and a Case Study, May 2009

2646 Francesco C. Billari and Vincenzo Galasso, What Explains Fertility? Evidence from Italian Pension Reforms, May 2009

2647 Kjell Arne Brekke, Karen Evelyn Hauge, Jo Thori Lind and Karine Nyborg, Playing with the Good Guys - A Public Good Game with Endogenous Group Formation, May 2009

2648 Guglielmo Maria Caporale and Luis A. Gil-Alana, Multi-Factor Gegenbauer Processes and European Inflation Rates, May 2009

2649 Henning Bohn, A Static Model for Voting on Social Security, May 2009

2650 Markus Haavio and Kaisa Kotakorpi, The Political Economy of Sin Taxes, May 2009

2651 Augusto de la Torre, María Soledad Martínez Pería and Sergio L. Schmukler, Drivers and Obstacles to Banking SMEs: The Role of Competition and the Institutional Framework, May 2009 
2652 Tobias Lindhe and Jan Södersten, Dividend Taxation, Share Repurchases and the Equity Trap, May 2009

2653 Assaf Razin and Edith Sand, Migration-Regime Liberalization and Social Security: Political-Economy Effect, May 2009

2654 Yin-Wong Cheung and Hiro Ito, A Cross-Country Empirical Analysis of International Reserves, May 2009

2655 Bart Cockx and Bruno Van der Linden, Flexicurity in Belgium. A Proposal Based on Economic Principles, May 2009

2656 Michael Melvin, Lukas Menkhoff and Maik Schmeling, Exchange Rate Management in Emerging Markets: Intervention via an Electronic Limit Order Book, May 2009

2657 Susanne Neckermann, Reto Cueni and Bruno S. Frey, What is an Award Worth? An Econometric Assessment of the Impact of Awards on Employee Performance, May 2009

2658 Steven Brakman, Harry Garretsen and Charles van Marrewijk, Economic Geography within and between European Nations: The Role of Market Potential and Density across Space and Time, May 2009

2659 Giovanni Facchini and Cecilia Testa, Reforming Legislatures: Is one House better than two?, May 2009

2660 Carsten Kowalczyk and Raymond Riezman, Trade Agreements, May 2009

2661 Oliver Falck, Stephan Heblich and Elke Luedemann, Identity and Entrepreneurship, May 2009

2662 Christian Lessmann and Gunther Markwardt, One Size Fits All? Decentralization, Corruption, and the Monitoring of Bureaucrats, May 2009

2663 Felix Bierbrauer, On the Legitimacy of Coercion for the Financing of Public Goods, May 2009

2664 Alessandro Cigno, Agency in Family Policy: A Survey, May 2009

2665 Claudia M. Buch and Christian Pierdzioch, Low Skill but High Volatility?, May 2009

2666 Hendrik Jürges, Kerstin Schneider, Martin Senkbeil and Claus H. Carstensen, Assessment Drives Learning: The Effect of Central Exit Exams on Curricular Knowledge and Mathematical Literacy, June 2009

2667 Eric A. Hanushek and Ludger Woessmann, Schooling, Cognitive Skills, and the Latin American Growth Puzzle, June 2009 
2668 Ourania Karakosta, Christos Kotsogiannis and Miguel-Angel Lopez-Garcia, Does Indirect Tax Harmonization Deliver Pareto Improvements in the Presence of Global Public Goods?, June 2009

2669 Aleksandra Riedl and Silvia Rocha-Akis, Testing the Tax Competition Theory: How Elastic are National Tax Bases in OECD Countries?, June 2009

2670 Dominique Demougin and Carsten Helm, Incentive Contracts and Efficient Unemployment Benefits, June 2009

2671 Guglielmo Maria Caporale and Luis A. Gil-Alana, Long Memory in US Real Output per Capita, June 2009

2672 Jim Malley and Ulrich Woitek, Productivity Shocks and Aggregate Cycles in an Estimated Endogenous Growth Model, June 2009

2673 Vivek Ghosal, Business Strategy and Firm Reorganization under Changing Market Conditions, June 2009

2674 Francesco Menoncin and Paolo M. Panteghini, Retrospective Capital Gains Taxation in the Real World, June 2009

2675 Thomas Hemmelgarn and Gaëtan Nicodème, Tax Co-ordination in Europe: Assessing the First Years of the EU-Savings Taxation Directive, June 2009

2676 Oliver Himmler, The Effects of School Competition on Academic Achievement and Grading Standards, June 2009

2677 Rolf Golombek and Michael Hoel, International Cooperation on Climate-Friendly Technologies, June 2009

2678 Martin Cave and Matthew Corkery, Regulation and Barriers to Trade in Telecommunications Services in the European Union, June 2009

2679 Costas Arkolakis, A Unified Theory of Firm Selection and Growth, June 2009

2680 Michelle R. Garfinkel, Stergios Skaperdas and Constantinos Syropoulos, International Trade and Transnational Insecurity: How Comparative Advantage and Power are Jointly Determined, June 2009

2681 Marcelo Resende, Capital Structure and Regulation in U.S. Local Telephony: An Exploratory Econometric Study; June 2009

2682 Marc Gronwald and Janina Ketterer, Evaluating Emission Trading as a Policy Tool Evidence from Conditional Jump Models, June 2009

2683 Stephan O. Hornig, Horst Rottmann and Rüdiger Wapler, Information Asymmetry, Education Signals and the Case of Ethnic and Native Germans, June 2009 
2684 Benoit Dostie and Rajshri Jayaraman, The Effect of Adversity on Process Innovations and Managerial Incentives, June 2009

2685 Peter Egger, Christian Keuschnigg and Hannes Winner, Incorporation and Taxation: Theory and Firm-level Evidence, June 2009

2686 Chrysovalantou Milliou and Emmanuel Petrakis, Timing of Technology Adoption and Product Market Competition, June 2009

2687 Hans Degryse, Frank de Jong and Jérémie Lefebvre, An Empirical Analysis of Legal Insider Trading in the Netherlands, June 2009

2688 Subhasish M. Chowdhury, Dan Kovenock and Roman M. Sheremeta, An Experimental Investigation of Colonel Blotto Games, June 2009

2689 Alexander Chudik, M. Hashem Pesaran and Elisa Tosetti, Weak and Strong Cross Section Dependence and Estimation of Large Panels, June 2009

2690 Mohamed El Hedi Arouri and Christophe Rault, On the Influence of Oil Prices on Stock Markets: Evidence from Panel Analysis in GCC Countries, June 2009

2691 Lars P. Feld and Christoph A. Schaltegger, Political Stability and Fiscal Policy - Time Series Evidence for the Swiss Federal Level since 1849, June 2009

2692 Michael Funke and Marc Gronwald, A Convex Hull Approach to Counterfactual Analysis of Trade Openness and Growth, June 2009

2693 Patricia Funk and Christina Gathmann, Does Direct Democracy Reduce the Size of Government? New Evidence from Historical Data, 1890-2000, June 2009

2694 Kirsten Wandschneider and Nikolaus Wolf, Shooting on a Moving Target: Explaining European Bank Rates during the Interwar Period, June 2009

2695 J. Atsu Amegashie, Third-Party Intervention in Conflicts and the Indirect Samaritan's Dilemma, June 2009

2696 Enrico Spolaore and Romain Wacziarg, War and Relatedness, June 2009

2697 Steven Brakman, Charles van Marrewijk and Arjen van Witteloostuijn, Market Liberalization in the European Natural Gas Market - the Importance of Capacity Constraints and Efficiency Differences, July 2009

2698 Huifang Tian and John Whalley, Trade Sanctions, Financial Transfers and BRIC's Participation in Global Climate Change Negotiations, July 2009 